\title{
The Students' Strategies in Online Learning Interaction: Exploring Politeness in Google Classroom during Covid-19 Pandemic
}

\author{
Elita Modesta Br. Sembiring ${ }^{1}$, Srisofian Sianturi ${ }^{2}$, Faido Marudut Pardamean Simanjuntak ${ }^{3}$, and Sri \\ Ninta Tarigan ${ }^{4}$ \\ 1,3 Universitas Methodist Indonesia, Medan, Sumatera Utara \\ ${ }^{2}$ Universitas HKBP Nommensen, Medan, Sumatera Utara \\ ${ }^{4}$ Universitas Prima Indonesia, Medan, Sumatera Utara \\ elitamodesta@gmail.com
}

\section{ARTICLE HISTORY \\ Received : 5 May 2021 \\ Revised : 13 May 2021 \\ Accepted : 15 August 2021}

\section{KEYWORDS}

Covid-19 Pandemic

Google Classroom

Online Learning

Online Interaction

Teacher-student Interaction

Linguistic Politeness

Positive Politeness Strategy

\begin{abstract}
Teacher-student politeness has been well-explored over the years, but mostly in direct or face-to-face communication. This study aims to fill the gap of politeness between students and educators in online learning, specifically in the sessions of one of the staple and most used educational platforms during the Covid-19 pandemic, namely Google Classroom. This study applies qualitative research method by describing the phenomenon of the language. This study observed the interaction of 36 English Literature Department students during their Google Classroom sessions from April to July 2021. The researchers analysed the students' interaction with their lecturer according to Brown and Levinson's politeness theory. Five politeness strategies were identified, namely the positive politeness strategies (i.e., greeting, gratitude and address term), negative politeness (i.e., apology) and vernacular language. The gratitude and address term expression conveyed by "Thank you, Mam" is dominantly used by students to minimize threat when giving comments for every instruction created by lecturer. Results of this study showed that the students use politeness strategies to ensure the effectiveness of online learning, yet they also limit their text-based interaction with the short expressions of politeness such as "Hi, mam" or "Yes, mam". This finding contributes to shedding light on the aspect of politeness in online interaction in Google Classroom and directs future studies to explore politeness in other contexts.
\end{abstract}

\section{Introduction}

The Covid-19 pandemic has changed all aspects of life. Since this pandemic appeared in early February 2020, it has limited humans' face-to-face interaction, as maintaining distance is one effort to prevent the transmission of the virus. For this reason, online communication has become the obligated form of communication. The curriculum of educational institutions from every corner have been radically revised to suit remote, distance, online, and digital forms of delivery (Murphy, 2020). Thus, interaction by online learning platforms is the most common in education today (Putri et al., 2020). In fact, Dhawan (2020) calls "online learning" as a "panacea" in the time of Covid-19 crisis.

Since distance learning is applied in most countries nowadays, many researchers have conducted studies on the use of online learning platforms such as Google Classroom, Google Meet, WhatsApp, Zoom, etc. The success of applying online learning platforms to replace physical learning method is still an interesting issue since this is a new era in global educational system. This is due to the heavily mixed results from hundreds of studies which reported the effectiveness and ineffectiveness of the abrupt implementation of online learning (Oktaria \& Rahmayadevi,
2021). The effectiveness ranged from how online platforms seems to streamline efficiency in material delivery between teachers and students (Pratiwi, 2020; Fuady, Sutarjo \& Ernawati, 2021; Atikah et al., 2021), increases select skills (Isda et al., 2021; Rosyada \& Sundari, 2021), and generates positive perception among the students (Priyadarshani \& Jesuiya, 2021; Vhalery, Alfilail \& Robbani, 2020; Hakim \& Mulyapradana, 2020).

At the same time, it seems that an equal number of studies also proved that online learning is entirely ineffective, generating much dissatisfaction among the students and teachers alike. The e-learning system's frequent network disconnection and internet data limitation are problems which occur on a day to day, if not hourly basis, so that online learning does not seem to encourage optimistic expectations (Putri, 2021; Susanto et al., 2021).

All those obstacles are found by some studies (Putri. 2021; Susanto et al., 2021). The difficulties are internet quota is limited, the signal is bad, even some of the students are not having smartphone or laptop. In addition, the low capability of using the online learning platforms made it difficult for teacher and students to do attendance menu, quiz assignment menu, essay assignment menu, word or pdf download menu, and video download menu. Even when students who attend 
online lectures at home with decent gadget and good signal, many still find online learning ineffective as the material understanding was less than optimal and too many assignments were given.

In light of the continuous uncertainty regarding effectiveness in online learning discourse, this study hones on to the interaction aspect of online learning. Previous studies on online learning seems highly focused on the cognitive realm, thus this study intends to cover the underexplored social realm. The various problems of online learning seem to stem from the fact that online learning limits students' face-to-face relationship. It appears that due to this reason, students are bored with the interaction in online learning (Li \& Dewaele, 2020). According to Yunitasari \& Hanifah (2020), students have little to no initiative to look forward to studying online because they could not meet with their friends and teachers directly. One study claims that online classes, whether live or recorded, can never substitute for interactive face-to-face classroom learning and practical sessions (John et al, 2021).

To establish an interactive learning in online learning is to communicate, and to create a comfortable interactive atmosphere is to communicate politely. Learning cannot be seperated from polite communication in order to create the harmonious relationship in achieving the learning objectives. In fact, many teachers and lecturers may be lost when faced with students who deliberately ignored politeness and are actively rude or trolling in learning process (Hamuddin et al., 2019; Khokhar, 2016). Classroom interaction helps students to involve in communication. It is believed to contribute the language development on students (Consolo, 2006). In clasroom interaction, teacher are guiding students in completing the tasks of linguistic problems and producting language through interaction. This is the reason why students develop their competences best in interaction (Thoms, 2012). Moreover, it is sthrengtened by Seedhouse \& Jenks (2015) that presented the aspects of language are learnt and taught in language classroom.

Researches on politeness in classroom context have been proposed by some writers. Senowarsito (2013) investigated the politeness strategies applied by EFL teacher and students in the class directly. Based on the classroom research, it found the positive politeness strategy is dominantly used by teacher and students in the class. The social distance, the age, the student's power, and the limitation of the linguistic ability influenced the choice of politeness strategies (Sapitri et al., 2020). They recognized themselves very well. It proved that teacher and students maintain the relationship. This is similarly supported by Adel (2016) that identified the Iranian EFL learners in the class. The result show that positive politeness strategy is dominantly used by teacher and students to minimize the face threat. As there is no Face Threatening Act (FTA) happens during the interaction, harmonious relationshipis maintained in the class. Politeness strategies applied by Indonesian lecturer and teacher in the class directly (face-to-face communication) has also been investigated by Sembiring \& Sianturi (2019). The research focused on student to student's interaction during the responding to the point of view in Cross Cultural Understanding class. As students communicated to their friends, no distance between them. They they communicate directly. As they are not reluctant to speak, they are polite in words but not in their acts.

These previous studies mainly focused on seeing the politeness strategies by teacher and students in face-to-face or direct communication in the class. Many researches have proven the use of politeness strategies in teacher student classroom interaction creates the effectiveness of learning process. The effective classroom interaction contributes to the success of the English language learning process. The communication in teaching is not only to transfer knowledge but also to create a comfortable atmosphere that can create solidarity and cooperation with the use of expressions such as greetings, gratitude and apology (Astuti 2017; Andi, 2018; Widana, 2018; Mahmud, 2019). In addition, Nugrahanto \& Hartono (2019), Heriyawati et al. (2019), Fitryani (2020) and Wijayanti, Wijayanto \& Marmanto (2020) proved the existing of the four types of politeness strategies and the dominant use of positive politeness strategies in the classroom interaction created effective interaction not only between teacher and students but also among the student body. Aside from greetings, gratitude, apology, Yusuf \& Anwar (2019) also found that English students apply vernacular language to soften their language during class presentations' discussions. In short, politeness strategies are significantly important in maintaining the comfortable environment in classroom interaction. This raises thehe question of how politeness strategies can achieve similar effects in online learning atmosphere. Wong \& Esler (2020) recently carried out a literature review on teaching and learning politeness studies, and the study pointed out the need to investigate how politeness is expressed in modern language. This gap on the current pandemic's online learning interaction's politeness is what this study intends to fill.

A staple educational online learning platform that is widely used during the pandemic is Google Classroom. As in face-to-face communication, the teacher and students also interact during the learning process, but the difference lies in that the interaction in Google Classroom is mediated only by text or words. In other words, textual language is the only tool used to implement the teaching and learning process. As far as the researcher is aware, there has not been any study that tries to identify the politeness strategies students employ in Google Classroom interaction, and there is still very few studies that investigate politeness among other speech acts in online learning context. Therefore, the results of this study will contribute significantly in the field of politeness studies.

\section{Literature Review}

\subsection{Politeness}

Politeness as one of ideology is seen as such a fixed and shared system. Furthermore, as both politeness and 
ideologies are associated with culture, culture becomes groups of basically like-minded people. Politeness is the term used to describe the extent to which action, such as the way we say something. Politeness means acing so as to take account of the feelings of others (Brown \& Levinson, 1987).

In relation to culture, politeness is created in society as the product of culture. as every individual has different culture, thus, the degree of politeness for every individual is also different. Politeness is rule which is created and applied among people during interaction one another. Politeness is called "manners". It is teaching people how to communicate among their society. People should follow the rule. Thus, when people ignore the rules, there will be social funishment given by the society itself. They will be called as arrogant, selfish even uncivilized (Sibarani, 2004). Echoed by Kadar \& Haught (2013), politeness is associated with norm or moral which is made by people in society. By the norm, people are taught to behave in social life. However, while politeness is affected by culture, it is also different among individuals. For this reason, the scale of politeness depends on the person.

Politeness in communication used to achieve one goal. The goal is saving image (face) both speaker and hearer in communication. Image (face) is the self esteem of speaker and hearer. It is believed, when face is saved, both speaker and hearer are maintaining the relationship. According to Brown \& Levinson (1987) presented there two types of face. They are positive face (the desire to be free) and negative face (the desire to be beneficial). Both these faces are saved to avoid the treat of face as it appears when the speaker and hearer creats the acts which treat the face. Brown and Levinson called as Face Threatening Act (FTA). They sthrengtened both positive and negative faces determine the way of being polite. The notion of face is sthrengtened by Spencer-Qatey (2008) and Culpeper (2011). Those two studies added the concept of face. It has a big role in norm created by society, thus, saving face in interaction is the most important. Besides those two faces, Meyerhoof (2011) sthrengtened that people apply different way of being polite as every individual is different. It depends on the closeness. It means, the way to communicate to someone that we recognize well will be different from someone that we do not know well. Thus, the closeness of relationship affects the way of being polite.

\subsection{Politeness Strategies}

Brown \& Levinson (1987) proposed the concept of face as the very important scale in communication. For saving the face, there is a way used to express the utterances as polite as possible. The way is then called as politeness strategy. As the central of the theory, the concept of the face are expected to be maintained by speaker and hearer during the communication. By maintaining the face, it is supposed to minimize the Face Threatening Acts (FTAs) such as disagreement even embarrasing during the communication. For the reason, Brown and Levinson proposed the the realization of politeness strategies into 25 politeness strategies. Those 25 politeness stretegies are classified into two categories. The politeness strategies are positive politeness strategy and negative politeness strategy. Positive politeness strategy is a strategy of speaking which is used a kind of metahporical extension of intimacy to imply coomon ground or sharing of wants to a limited extent between strangers who perceive themselves: for the purpose of interaction, while negative politeness strategy is a kind of strategy which redressive acrion addressed to the addressee's negative face: the want to have freedom of action unobstructed and attention unrestricted.

The positive politeness strategy can be realized into 15 strategies. They are (1) Notice, attend to hearer (his interests, wants, needs, goods). Speaker should take notice of aspects of hearer's condition (noticeable changes, remarkable possessions, anything which looks as though hearer would want S notice and approve of it. (2) Exaggerate (interest, approval, sympathy with hearer). This is often done with exaggerate intonation, stress, and other aspects of prosodic, as well as with intensifying modifiers. (3) Intensify, interest to hearer. Another way for speaker to communicate with hearer that speaker wants to intensify his/her interest to the conversation by 'making a good story'. The use of directly quoted speech rather than indirect reported speech is another feature of this strategy, as the use of tag questions or expressions that draw hearer as a participant into the conversation. (4) Use in-group identity markers. Speaker can implicitly claim the common ground with hearer that is carried by that definition of the group, including in group usages of address of address forms, of language or dialect, jargon, slang, and ellipsis. (5) Seek agreement. In this strategy, there are two ways to seek agreement, such as safe topics and repetition. "Safe topics" are used when speaker stresses his agreement with hearer and therefore to satisfy hearer's desire to be right", or to be corroborated in his opinions, for example talking about the weather, or the beauty of a garden. Besides, agreement may also be stressed by repeating part or the proceeding speaker has said, in a conversation and by using particles that function to indicate emphatic agreement. (6) Avoid disagreement. Speaker may do a white lie in order to hide disagreement, by doing this, speaker will not damage hearer's positive face. (7) Presuppose/ raise/ assert common ground. Speaker talks with hearer for awhile about unrelated topic to show that speaker is interested in hearer and indicate that speaker has not come to see hearer imply to do the FTA). This strategy is used for softening request. (8) Joke. Joking is a basic positive politeness technique, for putting hearer 'at ease' or it may minimize an FTA of requesting. (9) Assert or presuppose speaker's knowledge of and concern for hearer's wants. It is used to imply knowledge of hearer's wants and willingness to fit one's own in with them. (10) Offer, promise. Offer and promises are the natural outcome of choosing this strategy; even if they are false, they demonstrate speaker's good intentions in satisfying hearer's positive face wants. (11) Be optimistic. The speaker is very optimistic that the hearer will not mind to do the dishes that tonight. (12) Include both 
speaker and hearer in the activity. Speaker tends to use 'we' form when speaker really means 'you' or 'me', s/he can call upon the cooperative assumptions and thereby redress FTAs. (13) Give (or ask for) reason. In this strategy, speaker gives reasons as to why s/he wants. Hearer is led to see the reasonableness of speaker's FTA (or so speaker hopes). (14) Assume or assert reciprocity. Speaker asks cooperate with him/her by giving evidence of reciprocal rights or obligations between speaker and hearer. Thus, speaker may say, "I'll do X if you do Y for me" or "I did X for you last week, so you do Y for me this week" (vise versa). By pointing to the reciprocal right (or habit) of doing FTAs to each other, speaker may soften his/her FTA by negating the debt aspect and/or the face-threatening aspect acts such as criticisms and complaints. (15) Give gifts to hearer (goods' sympathy, understanding, cooperation). May satisfy hearer's positive-face want (that speaker wants hearer's wants, to some degree) by actually satisfying some of hearer's wants by some actions like gift-giving not only tangible gift, but human-relations wants such as the wants to be liked, admired, cared about, understood, listened to, and so on.

While negative politeness strategy is realised into 10 strategies. The strategies are (1) Be conventionally indirect. The speaker tries to be indirect so there can be no misinterpretation of what he means. In this case, the speaker uses understandable indirect speech acts. (2) Question hedge. It is used to modify the force of speech acts. (3) Be pessimistic. It gives redress to hearer's negative face by explicitly expressing doubt that the conditions for the appropriateness of speaker's speech act to obtain. It may be realized by doing indirect requests with assertions of felicity conditions which have had a negated probability operator inserted. (4) Minimize the imposition. Speaker redresses the seriousness of the FTA to pay hearer deference. (5) Give deference. There are two sides to the coin in the realization of the deference: one in which speaker humbles and abases himself and another where speaker raises hearer (pays him positive face of a particular kind, namely that which satisfies hearer' wants to be treated as superior). (6) Apologize. By apologizing for doing an FTA, the speaker can indicate his reluctance to impinge of H's negative face and thereby partially redress that impingement. (7) Impersonalize speaker and hearer. Speaker doesn't want to impinge on hearer is to phrase the FTA as if the agent were other than speaker, or at least possibly not speaker or not speaker alone, and the redresses was other than hearer, or only inclusively of hearer. This result is in a variety of ways of avoiding the pronouns 'I' and 'you'. (8) State the FTA as a general rule. Speaker doesn't want to impinge but is merely forced to by circumstances, is to state the FTA as an instance of some general social rule, regulation, or obligation. So, we get pronoun avoidance. (9) Nominalize. It shows formality which is associated with the noun end of the continuum. (10) Go on record as incurring a debt, or as not indebting hearer. Speaker can redress an FTA by explicitely claiming his indebtedness to hearer, or by disclaiming any indebtedness of hearer.

\subsection{Politeness Strategies in Online Learning}

Majority of existing studies investigates online learning in terms of how effective it is, while this study is interested in how the communication is dominantly mediated by text comments. Studies on politeness strategies in online learning, however, is still very limited in number. Megawati (2021) explored language politeness among English undergraduates in Jakarta as well. However, the study relied on online questionnaire and the aim was to describe the students' perception of language politeness. The study did not directly investigate or look at the way students interact, but found that students have positive perception regarding the politeness in online learning. This is supported by Citrawati et al. (2021) who found that positive politeness is also dominant among Balinese students. Another study also did not examine politeness strategies themselves, but only tested whether they were effective in fostering cooperation among the students in Borneo (Mardiana, 2021).

For studies that did directly examine for politeness in interaction, one study recorded the speech acts, which included politeness strategies, employed by three Indonesian high school teachers (Aditiya, 2021). Lin et al. (2020) investigated the role of politeness in online tutoring. It presented the result that tutors had a similar level of politeness at the beginning of all dialogues, while the students were noticeably more polite when they are solving problems. Other studies, instead of politeness, focused on impoliteness. Rachmawati, Hidayat, \& Kurniawan (2021) noted and recorded instances of impoliteness of an Indonesian lecturer in WhatsApp groups. Last but not least, Renhoard (2021) examined the language politeness among Papuan students and lecturers in WhatsApp and Zoom, finding that politeness principles were used to build effective communication between the two without having to eliminate the value of tolerance, respect, and appreciation for the speaker who has a higher status both in terms of age and educational status.

\section{Method}

This study employed the descriptive qualitative research in order to describe the phenomenon of politeness in the Google Classroom language use and interaction. The participants involved in this study were 36 English Department students at Universitas Methodist Indonesia. From April to July 2021 (four months), the researchers recorded the students' comments in their History of English Google Classroom, which covered 16 meetings for one semester. While observing the students' comments in their Google Classroom sessions, the researchers identified the types of politeness strategies that they employ according to Brown \& Levinson's 1987 politeness theory.

\section{Findings}

This study presents the transcripts of comments screenshots which showcases the politeness strategies that students employ in their Google Classroom interaction with 
their teacher. The politeness strategies portrayed included greeting, gratitude, address terms, apology, and vernacular language.

Lecturer: "Good morning all. Thank you for sharing your idea related to our previous explanation. Let me check your work then, share your score. I 11 see you bye. Gb"

Student: “Good Morning Mam.”

Student: "Good Morning Mam."

Student: “Good Morning Mam.”

Student: "Good morning mam, I am sorry to be late to send my assignment mam. I am in hometown, signal bad, May I send it again mam? Thank you mam."

Lecturer: "Yes, please, unfortunately minus 5 will be given to your score. Ok"

Extract 1

In comments on responding to the class instruction show that students dominantly gave response to the lecturer's instruction by saying "Good morning Mam". This way of greeting is commonly used to great people. Response of the students toward the instruction given by their lecturer show that students replied the greeting of their lecturer who greet them before. It was applied to get attention from the lecturer that students show their existence in the class. This was also the indicator that students have good manner in google classroom interaction. Students respect to their lecturer as the figure who has higher position in the class.

Lecturer: "What do you think about the story of Beowulf? Explain it briefly and clearly!"

Student: "Hi Mam, Ok Mam. I have send it mam, sorry if you find any errors to my assignment."

Student: "Hello Mam, I have send my assignment. Thank you Mam."

Extract 2

After sharing the assignment in google classroom, students leave the private comments by greeting their lecturer. They said "Hi, "Hello", then thank to their lecturer. It shows that students respect their lecturer even by leaving short comments to greet their lecturer. Different from the greeting in class instruction which lecturer greet the students first. Here, without greeting from the lecturer, students greet their lecturer. It is not replying greeting but more respecting to the lecturer.

In a small number of comments under the category of greeting, this study found a quirky phrase that elevates the respect conveyed in the online interaction.

Lecturer: "Good morning everyone. Due to the vacnication of Umi that will be held this coming Thrusday, I am so sorry, I can teach you at the time. I doesn't mean you are free of working something. Let me tell you to do the analysis of language used in Middle English period. We will discuss it a week later. Ok, I 11 see you and take care wherever you are. God bless you all."

Student: "Good morning Mam. Ok Mam. Stay healthy mam. Ok mam, God bless you too mam."

Extract 3
Greeting is also portrayed by saying "God bless you". It is greeting. Uttering this phrase in the closing of interaction indicated the respect to the religion. This way of greeting indicated that student has good manner of being polite. It not only indicates the relationship between the student and the lecturer, but also their relationship with God.

In addition, as it is online learning interaction, it needs internet connection. The comment stated by student show the difficulty faced by students during online learning interaction. It is true that positive impact of online learning is effective because student can learn from anywhere and anytime, but the requirement should be provided, that is internet connection. This student is luckly to do learning process when she is in her hometown, but in other case she had to be ready to face the problem. In fact, she was late for sending her task.

Lecturer: "Morning everyone. Stay healthy and happy wherever you are and whatever you do. For our class today, last week, your lecturer explained to you about the English Literature in Elizabeth period. You have given your little understanding about that. So, for today, your lecturer is sharing to you the summary of our topic. Read it more. I 11 see you and bye."

Student: "Thank you Mam"

Student:Thank you very much Mam”

Student: "Thank you mam, see you"

Extract 4

Here, students frequently used gratitude to respond the class instruction shared by lecturer. It is expressed by saying "Thank you Mam", "Thank you very much Mam" stated by every student. These show the politeness of the students to their lecturer. As it is in formal situation, students are aware about their position who really need the presence of the lecturer. Students do not think that this is the responsibility of lecturer as the person who has responsibility to teach. In Indonesia, it can be seen that student consider their lecturer as a hero then they have to thank to as there is the common proverb "guru adalah pahlawanku" (my teacher is my hero). Thus, by expressing gratitude, the students showed respect to their lecturer. In addition, the following extract also show the same case where students say thank in answering question.

Lecturer:" According to you, what aspects were being restored in restoration period? Give your answer briefly?"

Student: "Ok Mam"

Student: "Thank you very much Mam"

Student: "Hello Mam, thank you mam"

Student: "ok Mam, thank you”

Student: "ok Mam, we really appreciate it mam, thank you"

Student: “ I am sorry mem. yesterday, I have sent my file and I saw it was success mam, but you told us in Group Whatsapp that it has not being sent yet, I send it again mam, may I send it mam? Thank you mam."

Extract 5 
The extract shows that the students considered that the question is the way of measuring their understanding toward a topic in the lecture. For this reason, the students showed their appreciation for the question given by lecturer. In addition, though the question was not accompanied by any greeting from the lecturer, it seems that the students do not mind it. They keep respecting their lecturer by saying "thank you very much" in every comment.

Lecturer: Hi everyone. I am glad to see you again. For meeting 13 of our class today, you have to make sure that the project of final test should be sent a week before final. Your lecturer is going to remind you. Ok, Ill see you and take care wherever you are. Gb.

Student: "Ok Mam”

Student: "Sure Mam"

Student: :Thank you Mam"

Student: "Thank for remind us Mam/"

Student: "Ok Mam, but can I ask you mam? related to the task you have given us, should we hand in by email or google classroom as you haven't created a class in google classroom mam, thank you mam, God bless you mam."

Extract 6

This extract demonstrated the use of address terms "Mam" frequently. It is used to address to their female lecturer. It is addressed to a repectable person. Students consider their lecturer as their mother and they are the kids. By this, students are creating a harmonious relationship as they felt close to their lecturer. The use of another address term can be seen also by the following extract.

Lecturer: "How do you differ between English literature in Elizabeth
period and Puritan period? What makes them strongly different?"

Student A: "Sorry Mam, may I ask you Mam? Should we compare the periods mam? Thank you Mam.

Student B: "Yes lah [Name of Student A], i do ate, sorry Mam, heheheehe (Smiley)

Lecturer: "Answer your question, dear [Name of Student B]. Thank you dear (Happy Sticker)."

Student A: "Thank you [Name of Student B]. Thank you mam."

\section{Extract 7}

The use of addressing by pronoun "we" and personal names in Extract 7 show that student are familiar one another. As they are classmates, there is no metaphorical distance among them. Thus, they find it polite to use the first or given names of student and group pronoun in classroom interaction. The familiarity in the interaction can minimize the threat.

Lecturer: "Ok class, do this following instruction! Retell the story of Canterbury Tales by Geoffrey Chaucer by rewriting it. Use your own words briefly and clearly!"

Student C: "Excuse me mam, should we retell by video or writing mam?"

Student D: "Yes Mam, sorry for interrupting you, if video, what is the time mam? Thank you mam."

Extract 8
This extract show that student are really polite to ask their questions. They want to clarify the instruction stated by lecturer, then by asking the questions politely, they want to make it sure. Student C said "excuse me" first, before raising the question. The second comment/question by Student Dsaid "sorry" for taking time of her lecture then made sure about the instruction. Those ways of being polite minimized the face threat of lecturer. It created harmonious interaction because lecturer was respected and felt good and towards her students.

Student B: "Yes lah [Name of Student A], i do ate, sorry Mam, heheheehe (Smiley)

Lecturer: "Answer your question, dear [Name of Student B]. Thank you dear (Happy Sticker).”

Extract 9

In this extract, vernacular language is portrayed by students in interaction during answering the question. By saying " $i$ do ate" means is the vernacular language of student who is coming from Batak Toba ethnic group. Vernacular language is used to strengthen his statement. The student believe that his friend was more understand about the topic when he used vernacular language as the other student who was asking question also Batak Toba student.

\section{Discussion}

In the course of four months and 16 meetings, the researchers observed that students employ five politeness strategies, namely greetings, gratitude, address term, apology and vernacular language. Extracts 1, 2, and 3 showed the expressions of politeness strategy greeting. Greetings were used to minimize the distance between students and lecturer and to reduce the hearer's disappointment by expressing friendliness, which is in line with Brown \& Levinson (1987). Another study by Rahayuningsih (2019) also found the use of positive politeness strategies to show the solidarity and to maintain a close relationship between teacher and students and among students. It is also proven by Nurmawati, Atmowardoyo \& Weda (2019).

Gratitude as shown in Extracts 4 and 5, another positive politeness strategy, was primarily expressed by the students after the class instructions and questions were given by the lecturer. These strategies are in line with Brown \& Levinson's (1987) theory which indicates that expressing thanks is considered a polite way that can avoid the face threatening acts. Gratitude also indicates the solidarity above the power, such as proven by Mahmud (2019). In this study, the use of gratitude was directed to the respectable person. The students used this expression to convey that the assignments and tasks were not considered as burdens.

Address term is arguably the most used positive politeness strategy across the 16 Google Classroom meetings. As shown in Extracts 6 and 7, these were "Mam", personal names, and the pronouns "we" and "you". These address terms are considered as the "in-group Identity 
Markers" in Brown \& Levinson's theory (1987). The function of address term is to minimize the distance between speaker and hearer and also to reduce the hearer's disappointment by expressing friendliness. Mahmud (2019) similarly showed the use of address terms as in group identity markers that students frequently use during face-to-face classroom presentation. It is also explored by Fitriyani, Andriyanti (2020), who found that address terms were used to establish an honourable status to the lecturer. Using personal names as address term politeness strategy seems to have not been explored or mentioned in previous studies on online learning. This study sees that the use of personal names between students showed a closeness among the students. It reduced the distance as they are classmates.

Only one negative politeness strategy was observed in the Google Classroom interaction, namely the apology expressed with "excuse me" and "sorry", as shown in Extract 8. The use of this negative politeness strategies is to minimize the imposition. Brown \& Levinson (1987) said that apology functions as a way to express respect rather than friendliness, solidarity or intimacy. This is proven by the findings of this study as this expression is always used toward the lecturer as the person who has higher position than students.

Last but not least, the findings also showed that student used a vernacular language, " $i$ do ate" (yes, it is) in Extract 9, during the google classroom interaction. According to Brown \& Levinson, a vernacular refers to the language or dialect that is spoken by people that are inhabiting a particular country or region, typically the informal version of the native language. Other studies found usage of vernaculars as a softening mechanism for classroom presentations (Mahmud, 2019; Yusuf \& Anwar, 2019).

The findings above show that the politeness strategies are applied by students in google classroom interaction. Students kept politeness during the classroom interaction even by google classroom. The use of the politeness strategies created the comfortable class and increased student's interest. This finding supports the previous result that Google Classroom can effectively increase the students' interest in learning (Priyadarshani \& Jesuiya 2021; Hakim \& Mulyapradana 2020). The data also indicated the typical problem faced by students during online learning. Due to low internet connection, in one occasion, one student was unable to hand in her work on time. However, this problem can be solved by good communication between teacher and students. This result is in line Vhalery, Alfilail \& Robbani (2020).

An interesting contribution is that while this study shows that positive politeness strategies help students to cooperate well in learning, it seems to contrast the idea that positive politeness strategies can also contribute to the students' language development. This idea is proposed by Consolo (2006), who stated that polite communication can strengthen the language learners's competences in social interactions and relationships via positive communication with more experienced, knowledgeable, and competent speakers, in this case the lecturer (Thoms, 2012). Seedhouse \& Jenks (2015) also supported that the aspects of language such as language learnt and taught, method, syllabus and material are can be found in the classroom interaction. The result of this study indicated a different picture. Throughout the Google Classroom interaction, the researchers observed that students seem to not show the initiative to use language beyond politeness strategies. One or two students in each meeting would write and publish long comments in the Google Classroom, yet the majority of them would only give a short "Yes, mam" or "Thank you, mam". This may indicate that students are reluctant to interact more with the foreign language, and it can also indicate that online interaction does not seem to foster the students' language development and social competencies. This is markedly different with the results from previous studies on politeness strategies in the context of face-to-face classrooms, in which the politeness strategies employed truly did make way for students to freely express themselves (Sembiring \& Sianturi, 2019). The results agreed with Engzell, Frey, \& Verhagen (2021) who reported that there is a significant learning loss in terms of language development during the online learning process that is abruptly and globally implemented in response to the Covid-19 pandemic. Politeness strategies fostered a cooperative and effective learning process, but future studies are recommended figure out a way to engage the students to write more so that they do not only use short polite expressions in their text-based interaction. Findings might also prove to be different if explored in other text-limited platforms, such as blogs.

\section{Conclusion}

The positive politeness strategies (i.e., greeting, gratitude and address term), negative politeness (i.e., apology) and vernacular language, which are commonly identified to exist in the teacher- or lecturer-student interactions in face-to-face classrooms, are also identified in the online interaction in Google Classroom sessions. Results of this study showed that politeness strategies contribute to the effectiveness of online learning. However, the comments from students are also frequently limited in the short two-three words of greetings and address terms. This finding indicates that more communication strategies are needed to increase the online teacher-student interaction so that text-based interaction can go beyond the use of politeness strategies.

Research on politeness has flourished since Brown \& Levinson (1987) proposed their theory, yet there is still more room to explore. This study contributes to the field by filling the research gap on how politeness strategies is employed in Google Classroom interaction; previous studies have explored it in WhatsApp and Zoom, though future researchers can examine other commonly used online educational platform and compare. Furthermore, it is noticeable that most studies in the context of politeness strategies in classroom interaction, direct or indirect, seems to be mostly done by researchers from Indonesia, located in 
various educational institutions in the country, and also mostly involve English major students. Future exploration on politeness strategies invoked by students from other majors, ages and nationalities are, therefore, encouraged.

\section{References}

Aditiya, I. (2021). Speech Acts and Politeness Strategies Expressed by Pre-Service Teachers in Online Efl Learning in SMA Lab Undiksha (Doctoral dissertation, Universitas Pendidikan Ganesha).

Andi, S. M. (2018). The Application Of Politeness Strategies Among Teacher And Students In Classroom Interaction At Sma 1 Pamboang, Majene. IDEAS: Journal on English Language Teaching and Learning, Linguistics and Literature, 6(1). https://doi.org/10.24256/ideas.v6i1.16

Astuti, H.B. (2017). The Use of Politeness Strategies in the Conversation between Ben Whittaker and Jules Ostinin the Intern Movie. Yogyakarta shanata dharma university.(Online)(https://repository.usd.ac.id/9340/ 2/111214082_full.pdf,accessed 20 April 2021

Atikah, R., Prihatin, R. T., Hernayati, H., \& Misbah, J. (2021). Pemanfaatan Google Classroom Sebagai Media Pembelajaran Di Masa Pandemi Covid19. JURNAL PETIK, 7(1), 7-18. https://doi.org/10.31980/jpetik.v7i1.988

Brown, P. \& Levinson, S. (1987) Politeness: Some universals in language use. Cambridge; New York: Cambridge University Press.

Citrawati, N. K., Adnyani, N. L. P. S., Padmadewi, N. N., \& Suwastini, N. K. A. (2021). The Politeness Strategies Utilized by Postgraduate Students and Lecturers in Asynchronous online-learning Discussion. Lingua Didaktika: Jurnal Bahasa dan Pembelajaran Bahasa, 15(1), 22-35.

Culpeper, J. (2011). Impoliteness: Using Language to Cause Offence. Cambridge University Press. https://doi.org/10.1017/CBO9780511975752

Dhawan, S. (2020). Online learning: A panacea in the time of COVID-19 crisis. Journal of Educational Technology Systems, 49(1), 5-22.

Eelen, G. (2001). A Critique of Politeness Theories. St. Jerome: 225-250. https://doi.org/10.2307/798722

Fitriyani, S., \& Andriyanti, E. (2020). Teacher and Students' Politeness Strategies in EFL Classroom Interactions. IJELTAL (Indonesian Journal of English Language Teaching and Applied Linguistics), 4(2), 259.

https://doi.org/10.21093/ijeltal.v4i2.473

Fuady, I., Sutarjo, Moch. A. S., \& Ernawati, E. (2021). Analysis of Students' Perceptions of Online Learning Media During the Covid-19 Pandemic (Study of E- learning Media: Zoom, Google Meet, Google Classroom, and LMS). Randwick International of Social Science Journal, 2(1), 51-56. https://doi.org/10.47175/rissj.v2i1.177

Garfinkel, H. (1967). Studies of Routine Grounds of Everyday Activities. Social Problems, 11(3), 225-250

Hamuddin, B., Syahdan, S., Rahman, F., Rianita, D., \& Derin, T. (2019). Do They Truly Intend to Harm Their Friends?: The Motives Beyond Cyberbullying among University Students. International Journal of Cyber Behavior, Psychology and Learning (IJCBPL), 9(4), 32-44.

Haugh, M. (2013). Impoliteness, Social Practice and the Participation Order. Journal of Pragmatics, 58, 5272. https://doi.org/10.1016/j.pragma.2013.07.003

He, Y. (2012). Different Generations, Different Face? A Discursive Approach to Naturally Occuring Compliment Responsesin Chinese. Journal of Politeness Research, 8, 29-51 https://doi.org/10.1515/pr-2012-0003

Heriyawati, D. F., Siba, S. Y., \& Sulistyo, T. (2019). Lecturers' Politeness Strategies in EFL Classroom with Multicultural Background. LITERA, 18(3), 447464. https://doi.org/10.21831/ltr.v18i3.26494

Isda, I. D., Imran, I., Purwati, P., \& Rahmiati, R. (2021). The effectiveness of google classroom in teaching English during Covid-19 at SMA N 1 M. Payed. Journal of Research on English and Language Learning (JREaLL), 2(1), 202. https://doi.org/10.33474/jreall.v2i1.9518

John, M. R., Sharma, D. K., Poonuraparampil, J. A., \& Konuri, V. K. (2021). A study on the advantages and disadvantages of the online teaching program conducted in the Department of Anatomy, AIIMS, Raipur - students' perspective. National Journal of Clinical Anatomy, 10(1), 10-16. https://doi.org/10.4103/NJCA.NJCA_12_20

Kadar, D. Z., \& Haugh, M. (2013). Understanding Politeness. Cambridge University Press. https://doi.org/10.1017/CBO9781139382717

Khokhar, A. J. (2016, November). Why do teachers educators not practice what they believe: ict integration gaps. In ICERI 2016 Proceedings (pp. 6801-6810). IATED.

Li, C., \& Dewaele, J. M. (2020). The predictive effects of trait emotional intelligence and online learning achievement perceptions on foreign language class boredom among Chinese university students. Foreign Languages and Foreign Language Teaching, 5, 3344.

Lin, J., Lang, D., Xie, H., Gašević, D., \& Chen, G. (2020, July). Investigating the Role of Politeness in Human- 
Human Online Tutoring. In International Conference on Artificial Intelligence in Education (pp. 174-179). Springer, Cham.

Mahmud, M. (2019). The use of politeness strategies in the classroom context by English university students. Indonesian Journal of Applied Linguistics, 8(3), 597-606. https://doi.org/10.17509/ijal.v8i3.15258

Mardiana, D. (2021). The Effectiveness of Language Politeness and Cooperativeness-Based Online Learning Model In The Indonesian Language Lecture. Jurnal Bahasa, Sastra dan Pembelajarannya (JBSP), 11(1), 149-175.

Megawati, E. (2021). Students'perception Of Language Politeness In An Online Learning. Jurnal Smart, 7(2), 72-87.

Mills, S, \& Kadar, D. Z. (2001). Politeness and Culture. Cambridge University Press. https://doi.org/10.1017/CBO9780511977886.004

Mokhtar, R., \& Abu Karim, M. H. (2021). Exploring Students Behaviour in Using Google Classroom During Covid-19 Pandemic: Unified Theory of Acceptance and Use of Technology (UTAUT). International Journal of Modern Education, 3(8), 182-195. https://doi.org/10.35631/ijmoe.380015

Murphy, M. P. (2020). COVID-19 and emergency eLearning: Consequences of the securitization of higher education for post-pandemic pedagogy. Contemporary Security Policy, 41(3), 492505 .

Nugrahanto, A. D., \& Hartono, R. (2020). Politeness Strategies in Lecturer-Students Classroom Interaction at the Biology Class Sanata Dharma University. Atlantis https://doi.org/10.2991/assehr.k.200620.148

Nurmawati, N., Atmowardoyo, H., \& Weda, S. (2019). An Analysis of Positive Politeness Strategies to Promote Effective Interaction in The Classroom. ELS Journal on Interdisciplinary Studies in Humanities, 2(2), 171181. https://doi.org/10.34050/els-jish.v2i2.6340

Oktaria, A. A., \& Rahmayadevi, L. (2021). Students' Perceptions of Using Google Classroom During the Covid-19 Pandemic. International Journal of Educational Management and Innovation, 2(2), 153. https://doi.org/10.12928/ijemi.v2i2.3439

Pratiwi, E. W. (2020). Dampak Covid-19 Terhadap Kegiatan Pembelajaran Online di Sebuah Perguruan Tinggi Kristen di Indonesia. Perspektif Ilmu Pendidikan, 34(1), 1-8.

Priyadarshani, H. D. C., \& Jesuiya, D. (2021). Teacher's Perception on Online Teaching method during Covid-
19: With Reference to School Level Teachers at Faculty of Education, The Open University of Sri Lanka. Shanlax International Journal of Education, 9(2),132-140. https://doi.org/10.34293/education.v9i2.3662

Putri, D. C. Y. (2021). Perkuliahan Daring di Masa Pandemi Covid-19. Jurnal PTK Dan Pendidikan,6(2). https://doi.org/10.18592/ptk.v6i2.4151

Putri, S. E., Hamuddin, B., Nursafira, M. S., \& Derin, T. (2020). Discourse analysis in e-learning-based course using Moodle platform: An experimental design. REiLA: Journal of Research and Innovation in Language, 2(1), 19-26.

Rahayuningsih, D., Saleh, M., \& Fitriati, S. W. (2019). The realization of politeness strategies in EFL teacherstudents classroom interaction. English Education Journal, 10(1), 85-93.

Rahmawati, L. E., Hidayat, N., \& Kurniawan, A. (2021). Impoliteness of directive speech acts in online Indonesian language learning. Journal of Pragmatics Research, 3(2), 97-107.

Renhoard, N. (2021, April). Politeness Speech of Students and Lecture in Online Learning Process at A Polytechnic in Manokwari. In Thirteenth Conference on Applied Linguistics (CONAPLIN 2020) (pp. 360366). Atlantis Press.

Rosyada, A., \& Sundari, H. (2021). Learning from home environment: Academic writing course for efl undergraduates through google classroom application. Studies in English Language and Education, 8(2), 710-725. https://doi.org/10.24815/siele.v8i2.18374

Sapitri, P. A., Chasanah, A., Putri, A. A., \& Paulima, J. (2020). Exploring Brown and Levinson's Politeness Strategies: An Explanation on the Nature of the Politeness Phenomenon. REiLA : Journal of Research and Innovation in Language, 1(3), 111-117. https://doi.org/10.31849/reila.v1i3.3801

Sembiring, E.M. \& Sianturi, S. (2019). Politeness Strategies in EFL Classroom Context: Avoiding Future Conflict and Maintain the Harmony of Diversity. Utamax: The journal of Ultimate and Trends in Education, 1(3) https://doi.org/10.31849/utamax.v1i3.6257

Sharifian, F. (2011). Cultural Conceptualisation and Language: Theoritical Frameworkand Application. Johnbenjamins. https://doi.org/10.1075/clscc.1

Spencer-Qatey, H. (2008). Culturally Speaking: Managing Rapport through Talk across Cultures (2nd.ed). Continuum.

Susanto, E., Sasongko, R. N., Kristiawan, M., Nipriansyah, N., \& Purdiyanto, P. (2021). Constraints of Online Learning Using Google Classroom During Covid- 
19. Education Quarterly Reviews, 4(2). https://doi.org/10.31014/aior.1993.04.02.201

Vhalery, R., Nur Alfilail, S., \& Robbani, H. (2021). Persepsi Mahasiswa Tentang Pembelajaran Online "Google Classroom" Pada Minat Dan Motivasi Belajar. INTELEKTIUM, 2(1). https://doi.org/10.37010/int.v2i1.271

Wahyuni, S. (2019). Politeness Strategies in Students' Interaction. ELT Worldwide: Journal of English Language Teaching, 6(1), 67. https://doi.org/10.26858/eltww.v6i1.3358

Widana, I. M., Swandana, I. W., \& Wedhanti, N. K. (2018). An Analysis of Politeness Strategies Used by Teacher and Students of X IBB in SMAN 1 Sukasada During English Classroom Interaction. Journal of Psychology and Instructions, 2(2), 77. https://doi.org/10.23887/jpai.v2i2.15980

Wijayanti, W., Wijayanto, A., \& Marmanto, S. (2020). Native English Teacher's Politeness Realizations in EFL Classroom Interaction. ELS Journal on Interdisciplinary Studies in Humanities, 3(1), 31-40. https://doi.org/10.34050/els-jish.v3i1.9524

Wong, L., \& Esler, J. (2020). A Review of Teaching and Learning Linguistic Politeness. Journal of Critical Studies in Language and Literature, 1(4), 13-21.

Yunitasari, R. \& Hanifah, U. (2020). Pengaruh Pembelajaran Daring terhadap Minat Belajar Siswa pada Masa COVID 19. Edukatif: Jurnal Ilmu Pendidikan, 2(3), 232-243. https://doi.org/10.31004/edukatif.v2i3.142

Yusuf, R., \& Anwar, A. (2019). An Article Review on "The Use of Politeness Strategies in the Classroom Context by English University Students". Elsya: Journal of English Language Studies, 1(2), 69-73. https://doi.org/10.31849/elsya.v1i2.3530 